\title{
CAMBRIDGE لUURNALS
}
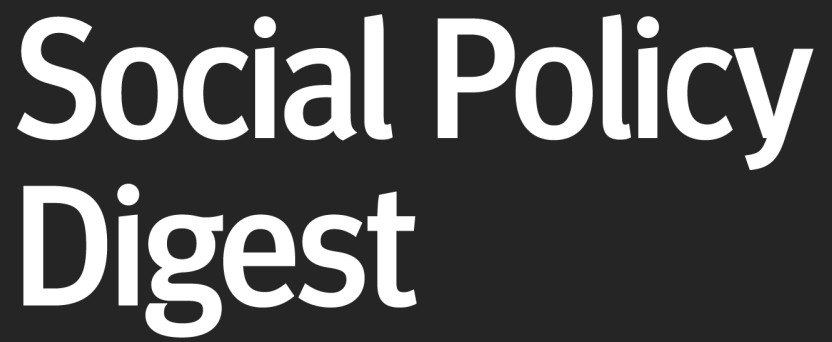

The Social Policy Digest is designed as a key online resource for all those working in UK social policy - policymakers, researchers, teachers and students, campaigners, journalists, and practitioners. It provides a categorized, and regularly updated, listing of relevant new developments across the whole social policy field.

Access to the Digest is now completely free.

The Digest database contains tens of thousands entries covering the period since 2002. Entries are organized by theme and time period, and can be searched. There is also a 'Latest News' listing and a news feed service, both of which are updated on a near-daily basis.

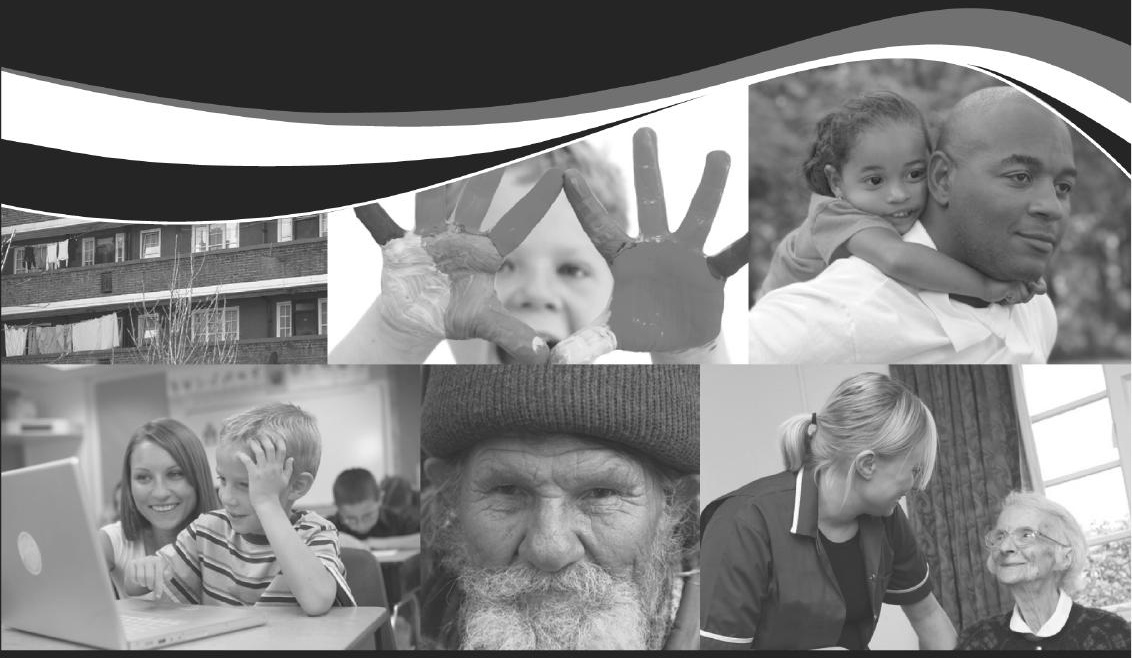

Find out more here: journals.cambridorge.orgh/spad 


\section{Notes for contributors}

All papers should be submitted using Manuscript Central through the journal's website at http://journals.cambridge.org/jid_ASO. All books for review should be sent to: Stella Allinson, Review Editors' Assistant, Ageing \& Society, School of Health and Social Welfare, The Open University, Walton Hall, Milton Keynes MK7 6AA, UK.

General approach and preparation of manuscripts

Authors are asked to bear in mind the multi-disciplinary and international readership when writing their contribution. In particular, care should be taken to draw out the implications of the analysis for readers in other fields, countries and disciplines. The stereotypical presentation of individuals or social groupings, including the use of ageist language, should be avoided.

Articles should generally contain between 3,000 and 9,000 words. All contributions (including reviews) should be typed double-spaced with at least one-inch or two centimetre margins throughout (including notes and the list of references). Most papers require the following sections in sequence: Title page, Abstract (of around 220 words), Keywords (three to eight), main text, Acknowledgements, NOTES, References, Correspondence Address. The tables and figures should be presented one to a page in sequence at the end of the paper.

The title page should give the title of the article and the author(s)' names, affiliations and postal and email addresses. Authors are asked to follow the current style conventions as closely as possible. Please consult a very recent issue of the journal. In particular, please note the following:

- Use the British variants of English-language spelling, so 'ageing' not 'aging'.

- First level headers are in bold, sentence case and left justified

- Second level headers are in italic (not bold), sentence case and left justified

- Do not number paragraphs or sections. Avoid very short (particularly one sentence) paragraphs. Do not use bold text in the text at all. For emphasis, use italic.

- In the main text, the numbers one to nine should be written as words, but for higher numbers the numerals (e.g. $11,23,364)$ should be used.

- All acronyms must be expanded on first use, even EU, USA, UK or UN, for those which are commonplace in one country are not in others.

- Do not use footnotes. Endnotes are permitted for technical and information details (including test statistics) that distract from the main argument. Endnote superscripts should be placed outside a punctuation mark (so. ${ }^{3}$ not ${ }^{4}$.).

- Write per cent (not \%) except in illustrative brackets.

\section{Citation of references}

Contributors may use either: (a) in-text citation of sources (author/date system); or (b) citation in notes.

(a) In-text citation. Give author's surname, date of publication and page references (if any) in parentheses in the body of the text, e.g. (Cole 1992: 251). For references with one to three authors, all authors should be named (Black, Green and Brown 2003). For references with four or more authors, the following form is required: (Brown et al. 2003). Note that all authors must be named in the list of references, and et al. is not permitted. A complete list, arranged alphabetically by authors' surname, should be typed double-spaced in the form:

Cole, T. 1992. The Journey of Life: A Cultural History of Aging in America, Cambridge University Press, Cambridge.

Elder, G. H. and Clipp, E. C. 1988. Wartime losses and social bonding: influences across 40 years in men's lives. Psychiatry, 51, 1, 177-98.

Ruth, J.-E. and Öberg, P. 1996. Ways of life: old age in life history perspective. In Birren, J. E., Kenyon, G., Ruth, J.-E., Schroots, J. F. F. and Svensson, T. (eds), Aging and Biography: Explorations in Adult Development. Springer, New York, 167-86.

(b) Citation in notes. References should be given in notes, numbered consecutively through the typescript with raised numbers, and typed double-spaced at the end of the article. Full publication details, in the same format as $(a)$, should be given in the notes when a work is first cited; for second and subsequent citations a short form may be used. For both styles of reference lists, please particularly note the following:

Authors are requested to minimise the citation of unpublished working and conference papers (because they are difficult for readers to acquire). Where they are cited, complete details of the title of the conference, the convening organisation, the location and the date of the presentation must be given.

Titles of Books and Journals are in Title Case and Italic.

Titles of papers, articles and book chapters are in sentence case and not italicised.

Page ranges for book chapters should always be given. Page ranges should be condensed, so 335-64 not 335-364, and S221-9 not S221-S229. Use (eds) and (ed.) where required. For journal paper references, part numbers must be given.

Citation of Internet pages or publications that are available online

Give author, date, title, publisher (or name of host website) as for a printed publication. Then follow with ... Available online at ... full Internet address [Accessed date].

Tables

Tables should be clearly laid out on separate pages, numbered consecutively, and designed to fit a printed page of $234 \times 155 \mathrm{~mm}$. Titles should be typed above the body of the table, with an initial capital only for the first word and proper names and italicised. Vertical lines should not be used and horizontal lines should be used only at the top and bottom of the table and below column headings. Authors are asked to give particular attention to the title and to column and row labels (they are often poorly selected, incomprehensible or inadequate). All multiple word labels should be in sentence case. Short titles that concentrate on the subject of the table are recommended. Technical or methodological details (such as sample size or type of statistic) should be described in table notes. Spurious accuracy should be avoided: most statistics justify only one decimal place.

Figures

Figures should also be provided on separate pages and numbered consecutively. Indicate in the margin of the typescript approximately where the tables and figures should appear. Do not convert figures to word 'Picture' format.

\section{Submission}

Submission of an article is taken to imply that it has not previously been published, and is not being considered for publication elsewhere. If an author is publishing a related article elswhere, this fact should be stated. Contributors of articles or reviews accepted for publication will be asked to assign copyright, on certain conditions, to Cambridge University Press. The Publisher reserves the right to typeset material by conventional means.

Proofs and offprints

First proofs may be read and corrected by contributors provided that they can give the Editor an address through which they can be reached without delay and guarantee to return corrected proofs to the Editor within seven days. The master proof will always be sent direct to the Editor by the printer; contributors will receive an email alert that the proofs are available at the printer's website address. Offprints may be purchased if ordered at proof stage. 
VOLUME 3 O PART I JANUARY 2 OI O

\section{CONTENTS}

3 Editorial: On the ethical maximisation of research publications

\section{Articles}

11 ALI ARDALAN, MONIR MAZAHERI, KOUROSH HOLAKOUIE NAIENI, MOHSEN REZAIE, FARIBA TEIMOORI and FARSHAD POURMALEK: Older people's needs following major disasters: a qualitative study of Iranian elders' experiences of the Bam earthquake

CHEMAITELLY, ZANA EL ROUEIHEB and ZEINAB N. SLIM: Work and mental health: the case of older men living in underprivileged communities in Lebanon

R. FERNÁNDEZ-BALLESTEROS, L. F. GARCIA, D. ABARCA,

E. BLANC, A. EFKLIDES, D. MORAITOU, R. KORNFELD, A. J. LERMA,

V. M. MENDOZA-NUMEZ, N. M. MENDOZA-RUVALCABA, T. OROSA,

C. PAUL and S. PATRICIA: The concept of 'ageing well' in ten Latin American and European countries

57 KAREN J. BURNELL, PETER G. COLEMAN and NIGEL HUNT: Coping with traumatic memories: Second World War veterans' experiences of social support in relation to the narrative coherence of war memories

79 PATRICK CLOOS, CAROLINE F. ALLEN, BEATRIZ E. ALVARADO, MARIA VICTORIA ZUNZUNEGUI, DONALD T. SIMEON and DENISE ELDEMIRE-SHEARER: 'Active ageing': a qualitative study in six Caribbean countries

103 FIONA KELLY: Recognising and supporting self in dementia: a new way to facilitate a person-centred approach to dementia care

125 SIOBHAN REILLY, JANE HUGHES and DAVID CHALLIS: Case management for long-term conditions: implementation and processes

157 KRISTINE THEURER and ANDREW WISTER: Altruistic behaviour and social capital as predictors of well-being among older Canadians

Reviews

183 K. WARNER SCHAIE and RONALD P. ABELES (eds): Social Structures and Aging Individuals: Continuing Challenges (Hans-Joachim von Kondratowitz)

184 DANUTA LIPINSKA: Person-centred Counselling for People with Dementia: Making Sense of Self (John Killick)

185 NINA TAUNTON: Fictions of Old Age in Early Modern Literature and Culture (Brian Worsfold)

188 VERN L. BENGTSON, DAPHNA GANS, NORELLA M. PUTNEY and MERRIL SILVERSTEIN (eds): Handbook of Theories of Aging (Bill Bytheway)

Cambridge Journals Online For further information about this journal please go to the journal website at: journals.cambridge.org/aso
Mixed Sources Product group from well-managed forests and other controlled sources www.fsc.org Cert no. SA-COC-1527
@ 1996 Forest Stewardship Council
CAMBRIDGE UNIVERSITY PRESS 